\title{
Construction and Empirical Analysis of the Evaluation Index System for Majors Set at Transportation Vocational Colleges
}

\author{
Bai Xiao, Mao Wei, and Duan Mingshe
}

\begin{abstract}
With the continuous advancement of the Belt and Road Initiative, the rapid development of the transportation industry is inseparable from the talent support of transportation vocational colleges, and the rationality of professional setting is an important factor affecting the development of higher vocational colleges. However, there is little evaluation of the majors set at transportation vocational colleges in existing researches. This paper attempts to construct an evaluation index system for majors set at transportation vocational colleges from four primary indexes of social needs, hardware facilities, software resources and student quality, as well as fourteen secondary indexes. Moreover, with Xinjiang Vocational \& Technical College of Communications taken as an example, an empirical test of the professional evaluation index system of transportation vocational colleges is carried out to verify the operability and practicality of the index system to comprehensively evaluate majors set at transportation vocational colleges.
\end{abstract}

Index Terms-Transportation, vocational colleges, major setting, evaluation index system.

\section{INTRODUCTION}

Since the Belt and Road Initiative was proposed in 2013, the top-level planning and design was completed in 2015, and the Belt and Road began to be fully implemented since 2016. Among them, facility connection made the fastest progress, which is inseparable from the talent support from transportation vocational colleges. Faced with the rapid development of the transportation industry in the new era, does the training of talents in transportation vocational colleges closely follow the development of the times? Whether the setting of majors can meet the need of current social development? The setting of majors plays a vital role

Manuscript received February 16, 2019; revised July 2, 2019. This work is supported by National Education Science 12th Five-Year Plan Youth Program of Ministry of Education - Study on Adaptability of Transportation Specialty and Transportation Industry Structure of Vocational Colleges in Xinjiang under the background of "One Belt One Road" Strategy (EJA150382). This work is also the phased research result of National Education Science 13th Five-Year Plan 2016 Annual Unit Funding Ministry of Education - Study on the Internationalization Development Strategy of Xinjiang Transportation Vocational Colleges under the background of "Silk Road Economic Belt".

Bai Xiao is with Faculty of Road Transportation and Management of Xinjiang Vocational and Technical College of Communications, Urumqi, Xinjiang, China (e-mail: $41468463 @$ qq.com).

Mao Wei is with Faculty of Road and Traffic of Xinjiang Vocational an Technical College of Communications, Urumqi, Xinjiang, China (e-mail: mw7397@qq.com).

Duan Mingshe is with Xinjiang Vocational and Technical College of Communications, Urumqi, Xinjiang, China (corresponding author; e-mail: 413662439@qq.com). in the development of higher vocational colleges. Therefore, it is of great practical significance for transportation vocational colleges to construct a scientific and reasonable professional evaluation system, evaluate and adjust their settings of majors. At present, there are basically few researches of the evaluation index system for majors set at transportation vocational colleges. This paper, taking transportation vocational colleges as the object, attempts to construct an evaluation index system for majors set at higher vocational colleges and conducts an empirical test with a transportation vocational and technical college as an example.

\section{IDEAS AND METHODS OF CONSTRUCTING THE INDEX SYSTEM}

At present, domestic scholars have made certain achievements in the research on the construction of evaluation index system for higher vocational colleges. Wu Jie has constructed the evaluation index system for majors set at higher vocational colleges from two primary indexes, i.e., result evaluation and process evaluation, three secondary indexes, i.e., education benefit, social benefit and internal benefit as well as thirteen third indexes, and then interpreted the system [1]. Wang Lijun constructed the evaluation index system for majors set at secondary vocational schools from four primary indexes, i.e., social demands, school running conditions, professional location and normative standards, as well as twelve secondary indexes and 32 third indexes [2]. There are also scholars who evaluate and analyze each major at colleges. For example, Hu Weiqing uses the fuzzy comprehensive evaluation model to empirically analyze each major from market demand, public demand, software resources and hardware resources, ranks the score of each major and proposes corresponding suggestions for the setting of majors [3]. Based on analyzing the decisive factors in the setting of majors for vocational education, Guo Yang and $\mathrm{Hu}$ Xiujin designed the "two-dimensional four-directional evaluation model" and explained the operation process of this method. In the same year, they modified the model to make it more operational [4], [5]. Shen Jun used "two effects" (efficiency and effect) as the evaluation value guide, and built the "four cores" (core objectives, core resources, core tasks, core development) as the main direction. Moreover, with the "four degrees" (the fitness of the target, the degree of security of the conditions, the effectiveness of the task, the satisfaction of the development) are taken as the key scale of the professional construction evaluation index system [6]. 
Subsequently, some scholars used the "two-dimensional four-directional evaluation model" to empirically test the setting of majors at many colleges and universities.

On the basis of combing the research results of domestic scholars, this paper intends to start from the factors affecting the professional setting of transportation-oriented higher vocational colleges in the new era and selects the main influencing factors to transform them into corresponding indicators, thus forming an objective, scientific and effective comprehensive evaluation. Indicator system. The entropy weight method is used to measure the weight, and the index is weighted and calculated, and finally the comprehensive evaluation value is calculated. Besides, 5-10 experts in relevant fields are invited to select and supplement the indexes in the index system, and adjustments are made according to experts' opinions, thus forming the final evaluation index system for majors set at transportation vocational colleges. Xinjiang Vocational \& Technical College of Communications is taken as an example for empirical test to verify the operability and effectiveness of the index system.

\section{SELECTION OF INDEX AND CONSTRUCTION OF EVALUATION SYSTEM}

\section{A. Principles Followed in the Selection of Index}

The construction of this index system follows three principles: the principle of making it both scientific and practical. Being scientific means the selection of indexes in the index system is scientifically based and being practical means the evaluation index system can be applied to practice, and effective verification result can be obtained to provide valuable reference for practice. The principle of making the system comprehensive and independent is also followed. Being comprehensive means to make the indexes as comprehensive as possible and try to include the influencing factors in the index system while being independent means each index is relatively independent when these indexes are arranged. Besides, qualitative analysis is combined with quantitative analysis. After the quantitative evaluation, qualitative analysis is carried out, and the results are adjusted as necessary to make the evaluation conclusion more reasonable.

\section{B. Basis of the Index System}

This paper mainly takes the transportation vocational colleges as the research object to build the evaluation index system for majors set at transportation vocational colleges. According to the scientific principle and practical principle, the talent demand structure should be considered in the construction of index system.

\section{Construction of the Index System}

According to the index system construction principle and based on comprehensively collating relevant literature, four primary index and 14 secondary indexes are selected combined with the structure of the transportation industry and features of the transportation vocational college, and a comprehensive evaluation index for majors set at transportation vocational colleges is constructed (Table I).
According to Luo Xia's ${ }^{1}$ division of the transportation industry structure, the transportation industry structure mainly includes three major categories of transportation infrastructure construction industry, transportation industry and professional transportation equipment industry .Transportation infrastructure construction industry includes specializes in or is primarily engaged in the construction of infrastructure (railroads, highways, airports, ports, etc.). Transportation industry includes three major categories of Transportation Class I, Transportation Class II and Auxiliary transportation industry. Transportation Class I includes Transportation companies that own or lease vehicles and transportation routes, and undertakes the whole process of transportation from carrier to delivery, such as railways (including national railways, local railways), urban rail transit companies, airlines, etc. Transportation Class II includes Transportation companies that have a part of transportation equipment or facilities to provide services for the transportation process, such as airports, automobile transportation companies, and highway transportation companies. Auxiliary transportation industry includes Enterprises that serve as passenger (goods) transport agents or undertake intermodal transport, packaging, information consultation, vehicle cleaning, and vehicle testing enterprises that provide road transport services. And Professional transportation equipment industry includes Specialize in transportation equipment and equipment manufacturing industry.

TABLE I: EVALUATION INDEX SYSTEM FOR MAJORS SET IN TRANSPORTATION VOCATIONAL COLLEGES

\begin{tabular}{|c|c|c|}
\hline $\begin{array}{l}\text { Primary } \\
\text { Index }\end{array}$ & Secondary Index & $\begin{array}{l}\text { Nature of } \\
\text { Index }\end{array}$ \\
\hline \multirow[t]{3}{*}{$\begin{array}{r}\text { A. Social } \\
\text { demand }\end{array}$} & $\begin{array}{l}\text { A1. The proportion of students } \\
\text { enrolled majors related to the } \\
\text { transportation infrastructure } \\
\text { construction industry and the } \\
\text { employment ratio of the industry }\end{array}$ & $\begin{array}{l}\text { Moderate } \\
\text { index }\end{array}$ \\
\hline & $\begin{array}{l}\text { A2. The number of students enrolled } \\
\text { in the transportation industry and the } \\
\text { employment ratio of the industry }\end{array}$ & $\begin{array}{l}\text { Moderate } \\
\text { index }\end{array}$ \\
\hline & $\begin{array}{l}\text { A3. The number of students enrolled } \\
\text { in the professional transportation } \\
\text { equipment industry and the } \\
\text { employment ratio of the industry }\end{array}$ & $\begin{array}{l}\text { Moderate } \\
\text { index }\end{array}$ \\
\hline \multirow[t]{3}{*}{$\begin{array}{l}\text { B. Hardware } \\
\text { infrastructure }\end{array}$} & $\begin{array}{l}\text { B1. Total value of major related } \\
\text { teaching equipment and total output } \\
\text { value of schools }\end{array}$ & $\begin{array}{l}\text { Positive } \\
\text { index }\end{array}$ \\
\hline & $\begin{array}{l}\text { B2. Major construction funds and } \\
\text { total annual education funds }\end{array}$ & $\begin{array}{l}\text { Positive } \\
\text { index }\end{array}$ \\
\hline & B3. Training base matching degree & $\begin{array}{l}\text { Positive } \\
\text { index }\end{array}$ \\
\hline \multirow[t]{5}{*}{$\begin{array}{l}\text { C. Software } \\
\text { resources }\end{array}$} & $\begin{array}{l}\text { C1. Student-teacher ratio of this } \\
\text { major }\end{array}$ & $\begin{array}{l}\text { Moderate } \\
\text { index }\end{array}$ \\
\hline & $\begin{array}{l}\mathrm{C} 2 \text {. Full-time and part-time teacher } \\
\text { ratio }\end{array}$ & $\begin{array}{l}\text { Moderate } \\
\text { index }\end{array}$ \\
\hline & $\begin{array}{l}\text { C3. Proportion of teachers work both } \\
\text { at school and enterprises }\end{array}$ & $\begin{array}{l}\text { Positive } \\
\text { index }\end{array}$ \\
\hline & C4. Teachers' title structure & $\begin{array}{l}\text { Positive } \\
\text { index }\end{array}$ \\
\hline & C5. Teachers' qualification structure & $\begin{array}{l}\text { Positive } \\
\text { index }\end{array}$ \\
\hline \multirow[t]{3}{*}{$\begin{array}{l}\text { D. Student } \\
\text { quality }\end{array}$} & $\begin{array}{l}\text { D1. Student employment rate in their } \\
\text { major fields }\end{array}$ & $\begin{array}{l}\text { Positive } \\
\text { index }\end{array}$ \\
\hline & $\begin{array}{l}\text { D2. Rate of students obtaining } \\
\text { diploma and degree certificate }\end{array}$ & $\begin{array}{l}\text { Positive } \\
\text { index }\end{array}$ \\
\hline & D3. Student employment satisfaction & $\begin{array}{l}\text { Positive } \\
\text { index }\end{array}$ \\
\hline
\end{tabular}


Explanation and description of the index meaning:

A1. The ratio of the number of students enrolled in the transportation infrastructure construction industry to the number of students employed in the industry: The number of students enrolled in the transportation infrastructure construction industry is classified according to the majors of transportation infrastructure construction in the "Catalogue of Higher Vocational Education Specialties (Majors) (2015)" The index is the number of students enrolled majors in the transportation infrastructure construction industry/the number of students employed in the transportation infrastructure construction industry.

A2. The number of students enrolled in the transportation industry and the employment ratio of the industry: The number of students enrolled in the transportation industry is classified according to the relevant transportation majors in the "Catalogue of Higher Vocational Education Specialties (Majors) (2015)". The index is the number of students enrolled in the transportation industry/the number of students employed in the transportation industry.

A3. The number of students enrolled in majors in the professional transportation equipment industry and the employment ratio of the industry: The number of students enrolled in majors in the professional transportation equipment industry shall be classified according to the relevant professional transportation equipment in the "Catalogue of Higher Vocational Education Specialties (Majors) (2015)". The index is the number of students enrolled in majors in the professional transportation equipment industry /the number of students employed in the professional transportation equipment industry.

B1. The total value of major related teaching equipment and the total output value of the school: The total value of major related teaching equipment (mainly including school teaching equipment, construction of related training room base, etc.) / total school output value.

B2. Major construction funds and school's annual education funds: major construction funds (mainly including financial allocations, funding for the Education Department, and funding for the establishment of the Human Resources and Social Security Department) / total annual education funding for the school.

B3. Training base matching degree: number of training bases / professional quantity.

C1. Student-teacher ratio of the major: the student-teacher should not be too high or too low, and the best internal shall be determined by relevant experts.

C2. Ratio between full-time teachers to part-time teachers: Full-time teachers refer to teachers who are employed to work full time at the school. Part-time teachers refer to teachers who are not an employed at the school or part-time teachers from enterprises. Ratio between full-time teachers to part-time teachers should not be too high or too low. Teachers from enterprises should account for a certain proportion at higher vocational colleges, and the best interval shall be determined by relevant experts.

C3. Proportion of teachers work at both school and enterprises: The total number of teachers with a non-teacher series of professional qualification certificates / the total number of teachers.

C4. Teacher title structure: Number of teachers with senior (including sub-high) titles (teacher series) / total number of teachers. "Upper limit" is set for this index, and a full mark is given to anyone who exceeds this limit.

C5. Teachers' degree structure: Number of teachers with a master's degree / total number of teachers. "Upper limit" is set for this index, and a full mark is given to anyone who exceeds this limit.

D1. Student employment rate in their major fields: Number of students employed in the transportation industry / total employment in the year.

D2. Rate of students obtaining diploma and degree certificate: The number of students who have obtained relevant professional qualifications/the total number of students.

D3. Student employment satisfaction: Obtained according to the results of the questionnaire from a third party (MYCOS).

TABLE II: THE RAW DATA OF EVALUATION INDEXES FOR MAJORS SET IN TRANSPORTATION VOCATIONAL COLLAGES

\begin{tabular}{|c|c|c|c|c|c|c|c|}
\hline Index & 2011 & 2012 & 2013 & 2014 & 2015 & 2016 & 2017 \\
\hline A1 & 1.4633 & 2.0804 & 1.7483 & 1.7848 & 1.3026 & 1.7522 & 2.1441 \\
\hline A2 & 1.4746 & 1.3357 & 2.0161 & 2.0573 & 1.7547 & 1.7799 & 1.9491 \\
\hline A3 & 1.3307 & 1.2166 & 1.3211 & 1.9726 & 3.3557 & 2.7382 & 2.5149 \\
\hline B1 & 0.2534 & 0.2534 & 0.2434 & 0.2112 & 0.1524 & 0.1824 & 0.1874 \\
\hline B2 & 0.6946 & 0.7486 & 0.5994 & 0.8225 & 0.7729 & 0.7053 & 0.6678 \\
\hline B3 & $43.48 \%$ & $38.46 \%$ & $51.72 \%$ & $66.67 \%$ & $60.61 \%$ & $71.43 \%$ & $88.57 \%$ \\
\hline $\mathrm{C} 1$ & 14.7517 & 15.5158 & 17.0147 & 19.2374 & 22.2837 & 23.7650 & 25.0417 \\
\hline $\mathrm{C} 2$ & 3.9733 & 4.2133 & 4.2625 & 4.9722 & 5.2353 & 8.1333 & 5.7313 \\
\hline $\mathrm{C} 3$ & 0.2248 & 0.2120 & 0.2962 & 0.2877 & 0.2893 & 0.2869 & 0.4688 \\
\hline $\mathrm{C} 4$ & $7.38 \%$ & $8.86 \%$ & $9.68 \%$ & $10.61 \%$ & $12.36 \%$ & $13.66 \%$ & $15.63 \%$ \\
\hline $\mathrm{C} 5$ & $34.56 \%$ & $43.35 \%$ & $42.23 \%$ & $40.78 \%$ & $41.85 \%$ & $41.80 \%$ & $40.36 \%$ \\
\hline D1 & $69.11 \%$ & $75.12 \%$ & $92.92 \%$ & $94.12 \%$ & $93.22 \%$ & $94.95 \%$ & $95.94 \%$ \\
\hline D2 & $98 \%$ & $98.25 \%$ & $98.10 \%$ & $98.25 \%$ & $97.54 \%$ & $75 \%$ & $80.54 \%$ \\
\hline D3 & $60 \%$ & $62 \%$ & $63 \%$ & $67 \%$ & $77 \%$ & $76 \%$ & $74 \%$ \\
\hline
\end{tabular}


the operability of the index system. Xinjiang Vocational \& Technical College of Communications is a comprehensive higher vocational college that trains transportation professionals. The College has four major transportation secondary schools including the School of Automotive Engineering, the School of Road and Bridge Engineering, the School of Mechanical and Electrical Engineering, and the School of Transportation Management as well as 35 majors.

\section{A. Data Source and Processing}

From the Xinjiang Statistical Yearbook, Xinjiang Education Yearbook, MYCOS, Xinjiang Vocational \& Technical College of Communications internal database, etc., this paper collects and collates the raw data of 14 secondary indexes of the professional setting evaluation index system of Xinjiang Vocational \& Technical College of Communications from 2011 to 2017(Table II).

\section{B. Determine the Weight of the Index System}

In this paper, the entropy weight method is used to give the index weights, and the interference of subjective factors can be excluded, so that the evaluation results are more objective and reliable (see Table III for the results).

TABLE III: EVALUATION WEIGHTS FOR MAJORS SET AT TRANSPORTATION

\begin{tabular}{cccc}
\hline Primary Index & Weight & $\begin{array}{c}\text { Secondary } \\
\text { Index }\end{array}$ & Weight \\
\hline A. Social & 0.000722 & A1. & 0.000068 \\
Demand & & A2. & 0.000056 \\
& & A3. & 0.000598 \\
\hline B. Hardware & 0.119668 & B1. & 0.049943 \\
Facilities & & B2. & 0.007590 \\
& & B3. & 0.062135 \\
\hline C. Software & 0.854913 & C1. & 0.371182 \\
Resources & & C2. & 0.003114 \\
& & C3. & 0.075241 \\
& & C4. & 0.400877 \\
& & C5. & 0.004499 \\
\hline D. Student & 0.024697 & D1. & 0.011292 \\
Quality & & D2. & 0.007101 \\
& & D3. & 0.006304 \\
\hline \hline
\end{tabular}

\section{Evaluation Interval Setting of Comprehensive}

\section{Evaluation Index System}

In this paper, the evaluation interval of the evaluation of majors set at transportation vocational colleges is divided into four states: excellent, good, qualified, and unqualified. The best interval for the indexes A1, A2, and A 3 in the table is $[1,1.5]$, the optimal interval for the $\mathrm{C} 1$ index is $[12,18]$, and the optimal interval for the $\mathrm{C} 2$ index $[2,3]$. The above indicators are all moderate indexes. Too high or too low values indicate that the index is not optimal, and the rest are positive indexes. The evaluation criteria scores corresponding to the four states are: excellent [80,100], good $[50,80]$, qualified $[20,50]$, and unqualified $[0,20]$. The higher the score, the more scientific and reasonable the major setting of higher vocational colleges. At the same time, combined with the meaning of the indexes, this paper sets the corresponding measurement range of the value of each index and the major setting standard score (Table IV).
TABLE IV: EVALUATION INTERVAL OF MAJORS SET AT TRANSPORTATION VOCATIONAL COLLEGES

\begin{tabular}{|c|c|c|c|c|}
\hline Index & $\begin{array}{l}\text { Excellent } \\
(80 \sim 100) \\
\end{array}$ & $\begin{array}{c}\text { Good } \\
(50 \sim 80)\end{array}$ & $\begin{array}{l}\text { Qualified } \\
(20 \sim 50)\end{array}$ & $\begin{array}{c}\text { Unqualified } \\
(0 \sim 20)\end{array}$ \\
\hline A1 & $1 \sim 1.5$ & $\begin{array}{l}0.8 \sim 1 \text { or } \\
1.5 \sim 1.8 \\
\end{array}$ & $\begin{array}{c}0.5 \sim 0.8 \text { or } \\
1.8 \sim 2.2 \\
\end{array}$ & $\begin{array}{c}0 \sim 0.5 \text { or } \\
\text { above } 2.2\end{array}$ \\
\hline A2 & $1 \sim 1.5$ & $\begin{array}{c}0.8 \sim 1 \text { or } \\
1.5 \sim 1.8 \\
\end{array}$ & $\begin{array}{c}0.5 \sim 0.8 \text { or } \\
1.8 \sim 2.2 \\
\end{array}$ & $\begin{array}{c}0 \sim 0.5 \text { or } \\
\text { above } 2.2\end{array}$ \\
\hline A3 & $1 \sim 1.5$ & $\begin{array}{c}0.8 \sim 1 \text { or } \\
1.5 \sim 1.8\end{array}$ & $\begin{array}{c}0.5 \sim 0.8 \text { or } 1.8 \\
\sim 2.2\end{array}$ & $\begin{array}{c}0 \sim 0.5 \text { or } 2.2 \\
\text { 以上 }\end{array}$ \\
\hline $\mathrm{B} 1$ & $0.3 \sim 1$ & $0.2 \sim 0.3$ & $0.1 \sim 0.2$ & $0 \sim 0.1$ \\
\hline $\mathrm{B} 2$ & $0.8 \sim 1$ & $0.5 \sim 0.8$ & $0.2 \sim 0.5$ & $0 \sim 0.2$ \\
\hline B3 & $0.8 \sim 1$ & $0.6 \sim 0.8$ & $0.4 \sim 0.6$ & $0 \sim 0.4$ \\
\hline $\mathrm{C} 1$ & $12 \sim 18$ & $\begin{array}{c}9 \sim 12 \text { or } \\
18 \sim 21\end{array}$ & $\begin{array}{l}6 \sim 9 \text { or } \\
21 \sim 26 \\
\end{array}$ & $\begin{array}{c}0 \sim 6 \text { or above } \\
26 \\
\end{array}$ \\
\hline $\mathrm{C} 2$ & $2 \sim 3$ & $1 \sim 2$ or $3 \sim 4$ & $0 \sim 1$ or $4 \sim 5$ & 0 or above 5 \\
\hline C3 & $0.6 \sim 1$ & $0.4 \sim 0.6$ & $0.2 \sim 0.4$ & $0 \sim 0.2$ \\
\hline $\mathrm{C} 4$ & $\begin{array}{c}0.2 \text { above } \\
100\end{array}$ & $0.15 \sim 0.2$ & $0.1 \sim 0.15$ & $0 \sim 0.1$ \\
\hline C5 & $\begin{array}{c}0.15 \text { above } \\
100\end{array}$ & $0.1 \sim 0.15$ & $0.05 \sim 0.1$ & $0 \sim 0.05$ \\
\hline D1 & $0.9 \sim 1$ & $0.7 \sim 0.9$ & $0.6 \sim 0.7$ & $0 \sim 0.6$ \\
\hline D2 & $0.9 \sim 1$ & $0.7 \sim 0.9$ & $0.6 \sim 0.7$ & $0 \sim 0.6$ \\
\hline D3 & $0.9 \sim 1$ & $\begin{array}{l}0.7 \sim 0.9 \\
\end{array}$ & $0.6 \sim 0.7$ & $0 \sim 0.6$ \\
\hline
\end{tabular}

Note: The appropriate interval for the $\mathrm{C} 1$ and $\mathrm{C} 2$ indexes is based on the "Notice of the General Office of the Ministry of Education on the Comprehensive Evaluation of the Work Level of Talent Cultivation in Higher Vocational Colleges". For the C4 and C5 indexes, the upper limit value is set, and a full mark is given to anyone who exceeds the upper limit In addition, the indexes are compiled according to relevant expert opinions. http://old.moe.gov.cn//publicfiles/business/htmlfiles/moe/moe_42/200409/1 182.html

\section{Calculation of the Comprehensive Evaluation Scores for Major Setting}

First, the specific scores of each index are obtained by mapping the index values to the mapping formula of the scores. Then according to the weight of the score combined with the weight of Table III, the comprehensive score of the professional setting evaluation of the transportation vocational colleges is obtained (Table V)

Mapping Formula for Positive Index:

$$
\begin{aligned}
& \text { Index score } \\
& =\text { upper limit of the score }- \text { (upper limit of evaluation - index value) } \\
& \times \frac{\text { highest score }- \text { lowest score }}{\text { upper limit of evaluation - bottom limit of evaluation }}
\end{aligned}
$$

Taking the $\mathrm{C} 4$ teacher title structure index as an example, according to Table II, its 2017 value is 0.1563 . Referring to Table IV, it can be seen that it falls within the excellent interval. Therefore, the evaluation score of $\mathrm{C} 4$ indicator is $80-(0.2-0.1563) \times(80-50) /(0.2-0.15)=53.78$

Mapping Formula of Moderate Index:

The calculation of moderate indexes is divided into two types. One is that the larger the value is, the better it is. When the index value is greater than (the upper limit of evaluation + the lower limit of evaluation), the formula is:

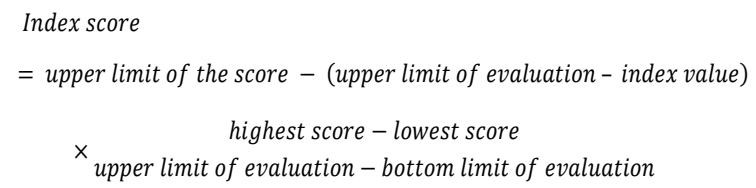


The other is that the smaller the value is when it is close to the optimal value, the better it is. When the index value is less than (the upper limit of evaluation + the lower limit of evaluation)/2, the formula is:

$$
\begin{aligned}
& \text { Index score } \\
& =\text { upper limit of the score }- \text { (index value - bottom limit of evaluation) } \\
& \times \frac{\text { highest score }- \text { lowest score }}{\text { upper limit of evaluation - bottom limit of evaluation }}
\end{aligned}
$$

TABLE V: COMPREHENSIVE EVALUATION SCORE OF TRANSPORTATION VOCATIONAL COLLEGES

\begin{tabular}{l|c|c|c|c|c|c|c}
\hline \hline Index & 2011 & 2012 & 2013 & 2014 & 2015 & 2016 & 2017 \\
\hline A1 & 81.47 & 28.97 & 55.17 & 51.52 & 87.9 & 54.78 & 24.19 \\
\hline A2 & 81.01 & 86.57 & 33.79 & 19.43 & 54.53 & 52.01 & 27.64 \\
\hline A3 & 86.77 & 91.34 & 87.16 & 24.11 & 2.9 & 12.03 & 15.33 \\
\hline B1 & $\mathbf{6 6 . 0 2}$ & $\mathbf{6 6 . 0 2}$ & $\mathbf{6 3 . 0 2}$ & $\mathbf{5 3 . 3 6}$ & $\mathbf{3 5 . 7 2}$ & $\mathbf{4 4 . 7 2}$ & $\mathbf{4 6 . 2 2}$ \\
\hline B2 & 69.46 & 74.86 & 59.94 & 82.25 & 77.29 & 70.53 & 66.78 \\
\hline B3 & $\mathbf{2 5 . 2 2}$ & $\mathbf{1 7 . 6 9}$ & $\mathbf{3 7 . 5 8}$ & $\mathbf{6 0}$ & $\mathbf{5 0 . 9 2}$ & $\mathbf{6 7 . 1 5}$ & $\mathbf{8 8 . 5 7}$ \\
\hline C1 & $\mathbf{8 9 . 1 8}$ & $\mathbf{9 1 . 7 3}$ & $\mathbf{8 3 . 3}$ & $\mathbf{6 7 . 6 3}$ & $\mathbf{4 2 . 3}$ & $\mathbf{3 3 . 4 1}$ & $\mathbf{2 5 . 7 5}$ \\
\hline C2 & 79.2 & 43.6 & 42.12 & 20.83 & 19.81 & 17.5 & 19.41 \\
\hline C3 & $\mathbf{2 3 . 7 2}$ & $\mathbf{2 1 . 8}$ & $\mathbf{3 4 . 4 3}$ & $\mathbf{3 3 . 1 6}$ & $\mathbf{3 3 . 4}$ & $\mathbf{3 3 . 0 4}$ & $\mathbf{6 0 . 3 2}$ \\
\hline C4 & $\mathbf{1 4 . 7 6}$ & $\mathbf{1 7 . 7 2}$ & $\mathbf{1 9 . 3 6}$ & $\mathbf{2 3 . 6 6}$ & $\mathbf{3 4 . 1 6}$ & $\mathbf{4 1 . 9 6}$ & $\mathbf{5 3 . 7 8}$ \\
\hline C5 & 100 & 100 & 100 & 100 & 100 & 100 & 100 \\
\hline D1 & $\mathbf{4 7 . 3 3}$ & $\mathbf{5 7 . 6 8}$ & $\mathbf{8 5 . 8 4}$ & $\mathbf{8 8 . 2 4}$ & $\mathbf{8 6 . 4 4}$ & $\mathbf{8 9 . 9}$ & $\mathbf{9 1 . 8 8}$ \\
\hline D2 & 96 & 96.5 & 96.2 & 96.5 & 95.08 & 57.5 & 65.81 \\
\hline D3 & 20 & 26 & 29 & 41 & 60.5 & 59 & 56 \\
\hline Total & $\mathbf{4 8 . 3}$ & $\mathbf{5 0}$ & $\mathbf{5 0 . 8 6}$ & $\mathbf{4 6 . 6}$ & $\mathbf{4 0}$ & $\mathbf{4 1 . 5}$ & $\mathbf{4 6 . 3}$ \\
score & & & & & & & \\
\hline \hline
\end{tabular}

\section{CONCLUSION}

Combined with the data of the Xinjiang Vocational \& Technical College of Communications and based on the results of the entropy weighting method, the weight of the software resource index is the largest among the four primary indexes in the evaluation index system for majors set at transportation vocational colleges. It is the main factor affecting the major setting of higher vocational colleges, followed by hardware facilities index, student quality index, and social needs index.

This paper constructs a evaluation system for majors set at transportation vocational colleges by scientifically selecting four primary indexes and fourteen secondary indexes, and empirically tests the indicator system through Xinjiang Vocational \& Technical College of Communications. Finally, through comprehensive weighted analysis, the professional setup of Xinjiang Vocational \& Technical College of Communications was qualified from 2012 to 2017 and food in 2012 and 2013.

The empirical test proves that the evaluation index system for majors set at transportation vocational colleges constructed in this paper is much operable and practical, and can be used to measure the setting of majors at other transportation colleges. The construction of this indicator system can also be appropriately improved, and applied to the evaluation of the setting of majors at non-transportation vocational colleges.

\section{CONFLICT OF INTEREST}

The authors declare no conflict of interest.

\section{AUTHOR CONTRIBUTIONS}

Bai Xiao wrote the paper; Mao Wei analyzed the data; Duan Mingshe collected the data and conducted the research; all authors had approved the final version.

\section{REFERENCES}

[1] J. Wu, "The elements, models and interpretation forms of the evaluation system for higher vocational professionals," China Higher Education Research, vol. 8, pp. 63-65, 2005.

[2] W. Q. Hu, "Fuzzy comprehensive evaluation of the relevance of majors set at higher vocational colleges," Vocational and Technical Education, vol. 28, pp. 46-49, 2007.

[3] Y. Guo and X. J. H, "The "two-dimensional four-directional evaluation model" for vocational education majors," Vocational and Technical Education, vol. 24, pp. 30-33, 2003.

[4] Y. Guo and X. J. Hu, "The revision of "two-dimensional four-directional evaluation model"," Vocational and Technical Education, vol. 24, pp. 32-34, 2003.

[5] R. S. Zhang, "Strengthening the construction of majors at vocational colleges by using major setting evaluation methods," China Vocational and Technical Education, vol. 34, pp. 58-59, 2012.

[6] J. Shen, "Practical research on CIPP evaluation model of professional construction in vocational colleges [D]," Southwest University, 2017.

Copyright $($ C 2019 by the authors. This is an open access article distributed under the Creative Commons Attribution License which permits unrestricted use, distribution, and reproduction in any medium, provided the original work is properly cited (CC BY 4.0).

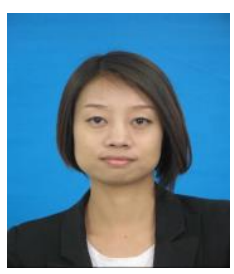

Bai Xiao was born in April, 1983. She got the doctor degree. She graduated from Shihezi University in 2015, majored in agricultural economical management, specialized in industrial economics, regional economics, vocational education and economic issues.

Since working in Faculty of Road Transportation and Management of Xinjiang Vocational and Technical College of Communications, she has hosted four projects including one national education information technology project, one soft science project of the Xinjiang Uygur Autonomous Region Natural Science Foundation, one Jiangsu Postdoctoral Research Funding Scheme Project and one The Xinjiang Uygur Autonomous Region Education Department Youth Teacher Training Fund Project. She also participated in several projects. She has published 20 more papers, three of which has included in CSSCI. In addition, she has acquired one utility model patents. At present, she focuses on the study of regional industrial economics development and vocational education and economy.

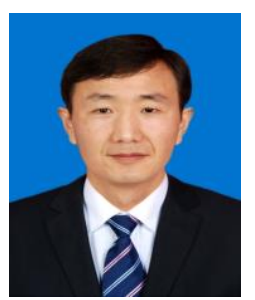

Mao Wei was born in April 1984. He got the doctor degree. He graduated from China University of Geosciences (Wuhan) in 2012, majored in geological engineering, specialized in vocational education and research works on engineering geology and geotechnical engineering.

He worked in Xinjiang Geological Environment Monitoring Institute after graduation. Since 2015, he works on teaching and research in Xinjiang Vocational and Technical College of Communications. He completed one National Education Planning Subject, one public geological hazard survey project of Xinjiang Uygur Autonomous Region, one project of China Transportation Education Research Association. He also participated in several projects including one Tackling Vital Project of Ministry of Transport Science and technology, one PublicInterest Project of China Geological Survey. He has published about 20 papers and acquired five utility model patents.

At present, Mr Mao is a member of Chinese Society of Rock Mechanics and Engineering and a super member of China Highway and Transportation Society. In addition, he is one of Xinjiang Uygur Autonomous Region "Hundreds of Young Doctors Introduction Plan" Talents as well as one of High Level Talents Training in the Xinjiang Uygur Autonomous Region Transportation System in the year 2018. 


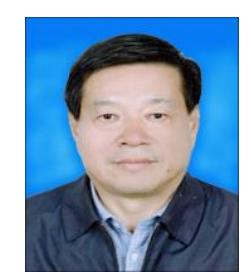

Duan Mingshe was born in March 1964. He is associated professor, graduated from Changsha University of Technology, majored in automobile transportation engineering, specialized in automobile transportation engineering and vocational education.

He works in Xinjiang Vocational and Technical College of Communications after gradudation. Now he is president of Xinjiang Vocational and Technical College of Communications. He has hosted one Project supported by the Ministry of education of China and one Key Project of Xinjiang Uygur Autonomous Region Communications Department. Recent years, he has published about 20 articles and 10 more textbooks as well as participated in several utility model patents. At present, he focuses on the study of
Development of Vocational Education Institutions and New Automobile Technology.

Since the execution of the "Silk Road Economic Belt" strategy, Mr Duan has attended relative meetings about Development and Communication oof International Education organized by Xinjiang Uygur Autonomous Region. In 2015, he participated in Demonstration of the "Silk Road Economic Belt" Educational Center Scheme of Xinjiang Uygur Autonomous Region. In the year 2016, he participated in the Formulating plan of "International Education Center" for students of Xinjiang Vocational and Technical College of Communications and students of Guiana and Kazakhstan. 